\title{
1. An introduction to intellectual property social justice and entrepreneurship: Civil rights and economic empowerment for the 21st century
}

Lateef Mtima

For those with access, the Internet is the worldwide means for sharing information, expressing ideas, and doing business - and an accepted fact of modern life. From national governments to neighborhood councils, from renowned universities to grade school tutors, from multi-national mega-corporations to web-based home businesses, the Internet is a means of global communication and commerce made manifest.

Given the Internet's present day significance and ubiquity, most people would be surprised to learn that in the Internet's early history, a single company had virtually sole control of the process through which individuals, organizations, and corporations could obtain a place on the Internet. In 1992, Network Solutions, Inc. was the sole bidder on a grant offered by the National Science Foundation for the development of a domain name registration service system for the Internet. Then as now, a domain name is the Internet address for one's web page or presence and is the means by which one enters and is located in cyberspace. As amazing as it seems, for years, a single company - Network Solutions - actually controlled a near monopoly on the gateway to the Internet.

And that company was the entrepreneurial brainchild of two African American men.

The story of Network Solutions ${ }^{1}$ is one that depicts the uneasy

1 The History of Network Solutions, accessed 10 October 2014 at http:// www.ultimatehostingreview.com/learn/networksolutions.html; A Brief History of NSF and the Internet, accessed 10 October 2014 at http://www.nsf.gov/news/ news_summ.jsp?cntn_id=103050; Kent D. Stuckey, Internet and Online Law, Sec. 7.07 (Law Journal Press, New York 2013); Issues Litigated Against Internet 
relationship that persists between historically marginalized groups and communities and the intellectual property regime. On the one hand it is an inspiring story of how two African Americans, Emmit J. McHenry and Tyrone Grigsby, acted upon McHenry's almost augural appreciation for the importance and potential of the Internet and its prospective impact upon intellectual property rights and commodities to build one of the pioneering business entities of the information age. At the same time, however, it is also the all too familiar story of how African American innovators were unable to obtain sufficient financial backing and other support from within either the black or white communities to sustain their beachhead in the Information New World. In order to meet the company's financial needs, McHenry and Grigsby often found it necessary to rely upon their two white partners to act as "front men" to negotiate with banks for business loans and to attract investors to participate in the company. ${ }^{2}$

Although McHenry, Grigsby and their partners helmed Network Solutions for several years, the continuing challenge of financing its operations eventually forced them to sell the company. Whether theirs is ultimately a story of success, however, depends upon one's viewpoint. In 1995, Network Solutions was sold for $\$ 4.8$ million, an impressive return for two black entrepreneurs at that time. On the other hand, five years later, the purchaser resold the company for \$21 billion. Today, many of the domain name registration functions over which Network Solutions had an early monopoly are administered by the Internet Corporation for Assigned Names and Numbers (ICANN). ${ }^{3}$

More than anything else, the story of Network Solutions is a modern allegory that illustrates the need for historically marginalized groups and developing nations to construct a new, propitious and more equitable relationship with the intellectual property legal and economic system. In the global information society, such groups and nations must expand their priorities to include the development, protection and commercial exploitation of intellectual property if they are to succeed in their struggles for social,

Corporation for Assigned Names and Numbers, 32 A.L.R. Fed 2d 561 (2013). For a general explanation of domain names see Umbro International, Inc., v. Canada, Inc., 1999 WL 117760 (Va. Cir. Ct.).

2 Gina Henderson, “debacle.com”, Emerge, p. 136, May 2000; Lauren deLisa Coleman, "Black Founder of Internet Domain Name Registry, Network Solutions, Reminisces on Racial Barriers in Tech Sector", The Grio, 28 June 2012, accessed 10 October 2014 at http://thegrio.com/2012/06/28/black-founders-of-internetdomain-registry-network-solutions-reminisce-on-racial-barriers-in-tech-sector/.

3 http://www.icann.org/en/about/welcome (accessed 10 October 2014); Coalition for ICANN Transparency, Inc. v. VeriSign, Inc., 611 F.3d 495, 500 (9th Cir. Cal. 2010). 
political and economic empowerment. Moreover, their intellectual property efforts and endeavors should be focused toward the digital information technology context and the concomitant prospects for socio-economic uplift. Digital information technological development and exploitation of intellectual property output presents unprecedented opportunities for socio-economic advancement and independence. ${ }^{4}$ If these opportunities are not timely and effectively seized, however, historically marginalized groups and developing nations will find themselves once again shackled into the bottom caste of the emerging global socio-economic order. ${ }^{5}$

While historically marginalized groups and developing nations are working to enhance their intellectual property portfolios and expertise, notably assisted by important efforts to increase Internet access and facility for those who remain unconnected, they must also take the lead in advocating for a doctrinal shift in the predominant intellectual property legal regimes and concomitant protection, exploitation and enforcement policies. Whereas most Western intellectual property regimes have been systemically deployed to abet and perpetuate the economic subjugation of historically marginalized groups and developing nations, in the global information society, intellectual property law and protection can and should be used to promote socio-economic development, parity and self-determination. Indeed, a fact rarely explored by intellectual property scholars or policy makers is that the intellectual property status and interests of historically marginalized groups in the developed world are more closely aligned with those of developing world communities than they are with the status and interests of their fellow developed world citizens. If Western intellectual property regimes are to remain relevant and viable in the post-colonial global community, the Western intellectual property perspective must be shifted away from the parallax view of intellectual property disenfranchisement and refocused toward the enlightened vantage point of intellectual property social justice. ${ }^{6}$

4 See e.g. Derek Slater and Patricia Wruuck, We Are All Content Creators Now: Measuring Creativity and Innovation in the Digital Economy, The Global Innovation Index 2012, 163. ("If the Internet were a sector, it would be larger than agriculture and utilities in many economies today. From 2004 to 2009, the Internet contributed $15 \%$ to GDP growth in the United States of America (USA) and on average $21 \%$ in mature economies studied by McKinsey Global Institute.")

5 Anthony G. Wilhelm, Digital Nation: toward an Inclusive Information Society, 59-61, 68-74 (MIT Press, Cambridge, MA 2004).

6 See Lateef Mtima, "Symposium: Intellectual Property and Social Justice", 48 How. L.J. 571 (2005); Seema Sirohi, “This Squeaky Wheel Needs No Oil”, The Hindu, accessed 10 October 2014 at http://www.thehindu.com/opinion/op-ed/thissqueaky-wheel-needs-no-oil/article4843669.ece. 
The reorientation of intellectual property law toward principles of social justice, coupled with the stimulation of beneficent intellectual property socio-economic enterprise in historically marginalized communities and developing nations, will engender a paradigm shift in the prevailing intellectual property ideologies. Indeed, equitable opportunity to benefit from the intellectual property system means far more than mere access to intellectual property output; social justice in this context entails a comprehensive examination of and correction to the entire range of factors that explicitly or tacitly extend, rather than cure, the prolonged disabilities of centuries of racism. As traditions of imperialistic misappropriation and cultural piracy are supplanted by policies that promote equitable participation in the global intellectual property cornucopia, intellectual property protection will enter an unprecedented phase of ecumenical Intellectual Property Empowerment. ${ }^{7}$

A socio-philosophical shift toward Intellectual Property Empowerment would provide important benefits to all stakeholders in the global intellectual property system. Historically marginalized groups and developing nations will obviously benefit from increased intellectual property development, use and commercial exploitation activity. Finally in control of their indigenous knowledge, innovations and artistic creations, historically marginalized groups and developing nations will begin to reap the benefits from their intellectual property resources and output. Moreover, as equal stakeholders in the global intellectual property repository, they will also gain enhanced access to the expressive information, technological "knowhow", pharmaceutical drugs and medicines and other advances developed by more established intellectual property rights holders, who would in turn be incentivized to barter for equitable intellectual property exchange and to collaborate in mutually beneficial intellectual property undertakings.

The benefits of Intellectual Property Empowerment to those currently vested in the prevailing intellectual property regimes will extend beyond

7 Stephen R. Munzer, "Corrective Justice and Intellectual Property Rights in Traditional Knowledge”, in Annabelle Lever (ed.), New Frontiers in the Philosophy of Intellectual Property (Cambridge University Press, Cambridge 2012), 58-87; Lateef Mtima, "What's Mine is Mine But What's Yours Is Ours: IP Imperialism, the Right of Publicity, and Intellectual Property Social Justice in the Digital Information Age", 15 SMU Sci. \& Tech. L. Rev. 323, 332-6 (2012); Llewellyn Joseph Gibbons, "Do As I Say (Not As I Did): Putative Intellectual Property Lessons for Emerging Economies from the Not So Long Past of the Developed Nations", 64 SMU L. Rev. 923 (2011); Danielle Conway-Jones, "Safeguarding Hawaiian Traditional Knowledge and Cultural Heritage: Supporting the Right to Self-Determination and Preventing the Comodification of Culture", 48 How. L.J. 737, 745-6, 751-6 (2005). 
access to the increased intellectual property output of historically marginalized groups and developing nations. Established rights holders will also enjoy enhanced respect for their own intellectual property rights and interests, as former "IP outsiders", having obtained a stake in the predominant intellectual property order, will become partners not only in intellectual property development and exchange but also in intellectual property education and anti-piracy initiatives. Under the rubric of Intellectual Property Empowerment, the developed powers can collaborate with historically marginalized groups and developing nations to establish a cohesive global intellectual property community.

This Introduction will present a theory of intellectual property social justice and posit how that theory might be delineated and tested by identifying an interrelationship between the American Civil Rights Movement and a proposed parallel movement for Intellectual Property Empowerment in the 21 st century. It will further argue that a social action plan of grassroots intellectual property education and social entrepreneurship are critical components to the success of such a movement. The chapter will close with a challenge to implement and test the theoretical proposition through mobilized collaborative action, as outlined and presented in the subsequent chapters of this book.

\section{ACHIEVING INTELLECTUAL PROPERTY EMPOWERMENT: SOCIAL JUSTICE CENTERED- LAW AND CIVIL RIGHTS ACTIVISM}

The pursuit of Intellectual Property Empowerment is nothing if not a global challenge of the first order to rectify unjust legal and economic norms. Just as the acknowledgement of human equality was the singular social value that ultimately led to a coalition of otherwise disparate groups in the Civil Rights Era, a social justice theory of intellectual property can similarly provide a unifying concept built on the social value of equity. First, such a theory should embody prescriptive norms based on progenitorial principles such as those made manifest in positive law frameworks such as the Constitution or natural rights edicts. Second, the theory should encompass the entirety of the target society's political economy. Finally, the theory should lend itself to some form of empirical testing or other social confirmation. Accordingly, intellectual property social justice theory proposes that:

The social utility objective that underlies protection for innovative and expressive output can only be achieved through legal norms that secure and enforce 
intellectual property rights in a socio-economic system regulated to guarantee equal opportunity for productive IP participation to all.

Toward this end, a combination of normative legal action and concomitant social action is proposed.

\section{Normative Legal Action}

The first step toward achieving Intellectual Property Empowerment is promoting pervasive adherence to the obligations of social justice in the development, interpretation and enforcement of intellectual property law. For decades, many courts and governing bodies have simply failed to correct or curtail institutionalized intellectual property injustice. For example, in the United States, African Americans and other marginalized groups have been systemically deprived of the commercial revenues and public recognition due from their intellectual property achievements. ${ }^{8}$ Even when confronted with uncontroverted evidence of intellectual property misappropriation and outright theft, courts have typically regarded these travesties as examples of the unwise or uneducated exercise of the freedom of contract, or "random" acts of race, gender or class exploitation, all beyond the purview of the intellectual property law. ${ }^{9}$ Consequently American courts often fail to do equity or otherwise administer social justice, on the grounds that providing such redress would distort the structure and integrity of the intellectual property regime.

In the developing world, Western misappropriation of the traditional knowledge and cultural expressions ("TKE") of indigenous peoples is as widespread as the pillaging of their natural resources. While Western

8 Patricia Carter Sluby, The Inventive Spirit of African Americans (Praeger, Westport 2004), 9-36; Melissa Harris-Perry, "The Harlem Shake", accessed 10 October 2014 at http://www.youtube.com/watch?v=mIgzzHOQWiA\&feature=y outu.be; K.J. Greene, “'Copynorms,' Black Cultural Production, and the Debate Over African-American Reparations", 25 Cardozo Arts \& Ent. L.J. 1179, 1183-9, 1196-9 (2008); Danielle M. Conway, "Intellectual Property: Implicit Bias and Gender Bias in Right of Publicity Cases and Intellectual Property Law Generally", in Justin D. Levinson and Robert J. Smith (eds), Implicit Bias Across the Law (Cambridge University Press, New York 2012), 179-82,; http://www.thenation. $\mathrm{com} / \mathrm{blog} / 173667 / \mathrm{i}$-shattered-my-leg-ncaa-tournament-and-all-i-got-was-lousy-tshirt?rel=facebook\#, accessed 10 October 2014.

9 See e.g. Gee v. CBS, 471 F. Supp. 600 (E.D. Pa 1979); Brooks v. The Topps Company, Inc., 86 U.S.P.Q. 2d 1361 (S.D.N.Y. 2007) (ultimately unsuccessful lawsuits commenced to protect African American intellectual property rights and interests, brought by the heirs of Bessie Smith and Baseball Hall of Famer James Bell respectively). 
intellectual property rights holders demand greater international protection for their own property rights, asserting them even in the face of health and education crises, many of these very same entities blithely ignore the rights and traditions of developing world communities, often relying upon Western precepts of intellectual property to justify their conduct. ${ }^{10}$ Given their past and continuing experiences, it is not surprising that many historically marginalized groups and developing nations have little interest in participating in or respecting Western intellectual property regimes.

The recognition of the fundamental social justice tenets of equitable inclusion, access and empowerment in the promulgation, interpretation and enforcement of intellectual property law would dismantle this unfortunate status quo. Intellectual property imperialism and institutionalized chicanery would be rejected as contravening the social utility objectives which underlie intellectual property protection. Moreover, the recognition of intellectual property social justice would not only preserve the interests of historically marginalized and developing nation innovators and creators, it would incentivize their full participation in systemic intellectual property endeavor. ${ }^{11}$

\section{Social Action}

Equally important to the realization of Intellectual Property Empowerment is the adoption of a progressive intellectual property social action platform. Whereas the recognition of social justice obligations in intellectual property law will enhance protection for the rights and interests of historically marginalized groups and developing nations, a correlative social action strategy is necessary to provide intellectual property education

10 See e.g. http://www.businessweek.com/articles/2013-10-24/africas-maasaitribe-seek-royalties-for-commercial-use-of-their-name\#p1, accessed 10 October 2014 (discussing unauthorized, commercial use of Maasai name and tribal indicia by multinational corporations). See further, Madahavi Sunder, From Goods to A Good Life: Intellectual Property and Global Justice (Yale University Press 2012), 2-3 (discussing Solomon Linda, the African composer of The Lion Sleeps Tonight, who died destitute while white American artists and entertainment conglomerates earned millions from the song). Indeed, many of these entities paradoxically assert that granting IP protection for TKE will shrink the public domain, which arguments not only beg the question, but are inconsistent with leading IP legal precedent. See e.g. Golan v. Holder, 132 S. Ct. 873 (2012).

11 Lateef Mtima, Symposium, "Copyright Social Utility and Social Justice Interdependence: A Paradigm for Intellectual Property Empowerment and Digital Entrepreneurship", 112 W. Va. L. Rev. 97, 126-9, 141-7 (2009). 
and to stimulate primordial intellectual property activity, particularly entrepreneurial intellectual property endeavor, within these communities. Through organized and entrepreneurial-minded "IP social activism", legal and entrepreneurial experts can collaborate with social activists and policy makers to open new avenues for economic empowerment, political selfdetermination and socio-cultural progress for communities and nations in need.

In constructing an Intellectual Property Empowerment social action platform, IP social activists might look to the American Civil Rights Movement, arguably the most effective socio-legal movement in modern history. ${ }^{12}$ Whereas many of the social inequities of the Civil Rights Era were grounded in socially pernicious laws and public policies, in the information society, some of the most pressing social inequities and injustices are tied to the intellectual property legal and economic infrastructure. Inequitable access to information and knowledge and various technological and pharmaceutical innovations can all be linked in part to socially indifferent and exploitative intellectual property mores. Intellectual property is therefore the contemporary analogue to the social/ legal equality agenda of the Civil Rights Era. The key intersection between the Civil Rights Movement and Intellectual Property Empowerment, however, is that Intellectual Property Empowerment provides a Civil and Human Rights Economic Agenda for the 21st Century, through which the unfinished economic business of the Civil Rights Movement can be pursued. Although the Civil Rights Movement achieved tremendous legal and social progress, it's the absence of a concrete economic agenda which left many historically marginalized groups and developing nations trapped in a state of economic subjugation and stagnation. ${ }^{13}$ These strategic links between the Civil Rights Movement and Intellectual Property Empowerment compel a comparative assessment of the history, legal foundation and social action framework of the Civil Rights Movement, toward the implementation of Intellectual Property Empowerment as a socio-economic movement.

12 See e.g. Tomiko Brown-Nagin, "Protest \& Polarization: Law and Debate in America 2012: Does Protest Work?" 56 How. L.J. 721, 723-5, 730-3, 741-3 (2013).

13 W. Sherman Rogers, The African American Entrepreneur, Then and Now (Praeger, Westport 2010), 3-14. 


\section{THE ANALYTICAL AND STRATEGIC INTERSECTIONS BETWEEN THE CIVIL RIGHTS MOVEMENT AND INTELLECTUAL PROPERTY EMPOWERMENT}

Every American school child is taught how the passage of the Emancipation Proclamation freed African Americans from chattel slavery. The realities of the century of African American dehumanization that followed, however, are not as widely discussed. ${ }^{14}$

For a brief time after the end of the Civil War, African Americans enjoyed a period of legal equality in America. Blacks were generally permitted to begin their lives as "freedmen", pursuing education and practicing trades, exercising the right to vote and even holding important public offices. ${ }^{15}$ However, as a result of a controversial presidential election in 1876, the constitutional rights of African Americans were sacrificed as the political price of resolving the electoral dispute. Southern democrats agreed to withdraw their objections to the election results in exchange for the end of federal involvement in the South's ongoing Reconstruction. ${ }^{16}$ Consequently Southern states were permitted to re-institute laws and policies mandating racial segregation, while private citizens formed terrorist organizations to quell black resistance, all without fear of federal intervention. African Americans were once again prevented from obtaining education, pursuing economic autonomy and exercising the right to vote. Even the basic human rights to be protected from murder, rape, unjust imprisonment and forced labor were denied them. ${ }^{17}$

Although the evisceration of the constitutional amendments which granted African Americans full citizenship had commenced in the legislative sphere, the death knell to black legal and civil rights was sounded when racially discriminatory laws and policies were given constitutional imprimatur by the United States Supreme Court. In Plessy

14 See Lerone Bennett, Jr., Before the Mayflower (5th edn, Penguin Books, 1984), 255-96; Robert Weisbrot, Freedom Bound: A History of America's Civil Rights Movement (W.W. Norton \& Co., New York 1990), 3-13.

15 Bennett, note 14 above, 214-54.

16 John Sibley Butler, Entrepreneurship and Self Help Among Black Americans (State University of New York Press, Albany 1991), 63-4; Rogers, note 13 above, $50-1$.

17 Joanne Grant, Black Protest: History, Documents, and Analyses, 1619 to The Present (Fawcett Publications, Robbinsdale 1968), 175-9; Genna Rae McNeil, Groundwork: Charles Hamilton Houston and the Struggle for Civil Rights (University of Pennsylvania Press, Philadelphia 1983), 5-7. 
v. Ferguson, ${ }^{18}$ the Supreme Court ruled that state laws which mandated "separate but equal" public accommodations for whites and blacks did not impose any "badge of servitude" upon blacks, nor did they designate blacks as inferior merely by "distinguishing" them from whites. Thus the legal and social subjugation of blacks was effectively held to be constitutionally permissible. For decades thereafter, African Americans endured the stigma of "Jim Crow"19 racial discrimination, until an effective legal challenge to Plessy could be formulated and advanced through the courts.

\section{Charles Hamilton Houston: The Legal Architect of the Civil Rights Movement}

Beginning in the 1930s, Charles Hamilton Houston, the progenitor of Howard Law School, ${ }^{20}$ devised an Equal Protection-centered assault on Plessy, which on its face did not challenge America's system of legal apartheid but rather, sought to enforce it. ${ }^{21}$ The genius of Houston's strategy was its practicality: one of the key reasons that Jim Crow "worked" was the fact that whereas governmental authorities pervasively enforced its directive of separation, no efforts were made to comply with its corollary mandate of equality. Thus Jim Crow in practice actually violated the terms of Plessy, which held that the constitutional price for racial segregation was the provision of "equivalents" for blacks. If governmental authorities were required to in fact provide blacks with equivalent institutional facilities and opportunities, however, the tab for Jim Crow would prove to be a bill they simply could not afford. Houston therefore reasoned that if the states were actually required to establish equal albeit separate institutions for blacks, allowing blacks full access to white institutions would be their only viable recourse.

Throughout a period that stretched over 20 years, Houston and his disciple Thurgood Marshall worked with the NAACP and other black organizations to pursue Houston's legal strategy in a series of cases in state and federal courts, and ultimately before the United States Supreme

18163 U.S. 537 (1896). In Plessy an African American citizen brought suit against the state of Louisiana, arguing that the state law that required him to give up his seat on a public train and move to a "colored section" violated his constitutional rights under the Thirteenth and Fourteenth Amendments.

19 Bennet, note 14 above, 255-9.

20 McNeil, note 17 above, 69-85.

21 McNeil, note 17 above, 115-17, 129-39, 150-1; Rawn James, Jr., Root and Branch: Charles Hamilton Houston, Thurgood Marshall, and the Struggle to End Segregation (Bloomsbury Press, New York 2010), 65-8, 73-4. 
Court. Beginning with Murray v. Maryland ${ }^{22}$ in 1935 and Missouri ex. rel. Gaines v. Canada ${ }^{23}$ in 1936, Houston carefully mounted a constitutional challenge to racial segregation in public education, arguing that state law schools that denied admission to black applicants violated their constitutional rights because the states had not established any alternative black law schools which these applicants could attend. ${ }^{24}$ Ironically in Murray, Houston and Marshall were actually able to assure the state trial court that a decision in favor of the plaintiff would be consistent with existing legal precedent and indeed, was required by Plessy.

Houston's litigation campaign reached its apotheosis in the landmark case of Brown v. Board of Education. ${ }^{25} \mathrm{Up}$ until then, Houston's legal victories hacked away at Jim Crow segregation by demonstrating that it was a socio-legal institution unconstitutional in practice; in Brown, Marshall argued to the United States Supreme Court that Jim Crow was inherently unconstitutional, in that legally enforced isolation of a minority group by society's majority bestows an indelible social and psychological stigma upon that minority group. ${ }^{26}$ More than a half century after its infamous decision in Plessy, the Supreme Court accepted these arguments, and directed that the policy of separate but equal be abolished from public education and that public schools be racially integrated "with all deliberate speed". The meticulous erosion of Jim Crow which began in Murray and Gaines had achieved its tactical metamorphosis with the Court's overruling of Plessy, and Brown marked the beginning of the affirmative dismantling of apartheid in American law and public policy.

\section{Beyond the Courts: The Civil Rights Social Action Platform}

While Houston's legal theories provided the litigation framework for the Civil Rights Movement, he and the other architects of the Movement understood that the eradication of de jure racial discrimination alone would not provide full legal and social equality for blacks in America. ${ }^{27}$ Because racial discrimination against blacks was a legally sanctioned public policy, the initial focus was necessarily directed toward changing the law. But Jim Crow was more than just a statute on the books: racial

\footnotetext{
$22169 \mathrm{Md} .478$ (1936).

23305 U.S. 337 (1938).

24 James, note 21 above, 68-74; 117-18.

25347 U.S. 483 (1954).

26 Weisbrot, note 14 above, 11; Grant, note 17 above, 253.

27 Juan Williams, Eyes on the Prize: America's Civil Rights Years 1954-1965 (Penguin Books 1987), 60, 122-61; McNeil, note 17 above, 170-1.
} 
animus and discrimination toward blacks was the way of life in America, and thus the initiative for racial justice would begin with black political and social leaders who helped African Americans to aspire and organize toward the full legal and civil franchise.

In the post-Reconstruction era, various political and social leaders came to prominence within the black community, each propagating a different school of thought on redressing the plight of African Americans. Most prominent was Booker T. Washington, the founder of Tuskegee Institute, who advocated that blacks should eschew political agitation and instead focus their attentions on pursuing whatever economic and other opportunities Jim Crow left available to them, and thereby advance themselves in ways such that whites would come to see for themselves that racial discrimination against blacks was a disservice to the nation. ${ }^{28} \mathrm{At}$ the beginning of the 20th century, W.E.B. Du Bois emerged as the leading proponent for full equality for blacks, directly challenging Washington's policies of socio-political conciliation..$^{29}$ Du Bois urged African Americans to press for immediate legal and social equality and reasoned that educated blacks, a "Talented Tenth", would be able to lead the community in undertaking the rights and privileges of full citizenship. Throughout the 1920s and 1930s, Marcus Garvey in turn provided a counterweight to $\mathrm{Du}$ Bois. The first internationally prominent black leader to spread an uncompromising message of black racial pride, Garvey argued that blacks in the New World needed first to shed the racial inferiority complex foisted upon them through slavery and reinforced under Jim Crow, and thereafter repatriate to Africa and build their own independent nation..$^{30}$

As conditions worsened for African Americans and the federal government repeatedly reneged on its promises to protect their civil and human rights, it became increasingly difficult for many blacks to accept Washington's philosophy of patient acquiescence. Moreover, while Du Bois and Garvey each struck emotional chords with their uncompromising rejection of white supremacy, many African Americans had difficulty envisioning a life outside of America, and thus Du Bois' philosophy of full equality "at home" ultimately gained prominence.

28 Booker T. Washington, Up from Slavery (Doubleday Page, New York 1901), 105-15.

${ }^{29}$ Manning Marable, Black Leadership (Columbia University Press, New York 1998), 41-6; Bennett, note 14 above, 330-3.

30 Marcus Garvey, Philosophies and Opinions of Marcus Garvey (Amy JacquesGarvey (ed.)) (Atheneum 1923), 17-18, 26, 47, 52-4, 68-72; Grant, note 17 above, 179; McNeil, note 17 above 8-9. Indeed, some African Americans did emigrate to the Pepper Coast of Africa and subsequently founded the Republic of Liberia. 
In 1909, Du Bois joined a group of prominent white liberals and black activists in organizing the National Association for the Advancement of Colored People ${ }^{31}$ its formation instigated by the infamous Springfield, Illinois race riot of $1908 .^{32}$ Much the same as how Houston meticulously established the legal precedent that would culminate in Brown, for decades the NAACP explored various social protest stratagems through which to construct a social action platform for African American civil rights. Long before Rosa Parks refused to give up her seat on a public bus in 1955, the NAACP had been confronted with occasions whereupon black passengers were jailed for refusing to relinquish their seats to whites. ${ }^{33}$ The NAACP saw in Parks, however, a lodestar which could arouse blacks and perhaps even induce sympathy from whites. ${ }^{34}$ An NAACP secretary and Youth Council adviser, the demure, bespectacled seamstress seemed the perfect symbol of quiet but righteous resistance to an unjust regime. The ensuing Montgomery Bus Boycott would not only lead to the desegregation of public transportation in Montgomery, Alabama, it would ultimately ignite a nationwide grassroots movement of student lunch counter sit-ins, a tactic originated by the Congress of Racial Equality in the 1940s, which in turn would prod the established civil rights leadership toward a more aggressive campaign of civil disobedience. ${ }^{35}$

The Montgomery Bus Boycott would also serve as the watershed moment at which Dr. Martin Luther King would come to national prominence, and wherein he and activist James Lawson would infuse the philosophy of passive non-violent resistance into the Movement's civil protest strategy. ${ }^{36}$ Dr. King understood that it was vital that the burgeoning movement for racial equality evoke the moral empathy of the American

31 Previously in 1905, Du Bois and the activist/journalist Monroe Trotter organized the Niagara Movement, the functional predecessor to the NAACP and the first major social activist organization dedicated to the cause of African American legal and social equality, so named to reflect "the mighty current of change" it was intended to bring about. See Grant, note 17 above, 206-14; Manning Marable note 29 above, 42; McNeil, note 17 above, 86-7; Bennett, note 14 above, 333-6; http://en.wikipedia.org/wiki/Niagara_Movement, accessed 10 October 2014.

32 Bennett, note 14 Jr., 337-9.

33 Williams, note 27 above, 60-63, 70.

34 Williams, note 27 above, 66; Grant, note 17 above, 251-2, 276-80.

35 Sara Bullard, Free At Last: A History of the Civil Rights Movement and Those Who Died in the Struggle (Oxford University Press, New York 1993), 16-29; Weisbrot, note 14 above, 13-14; Grant, note 17 above 255; Williams, note 27 above, 126-32, 140-2.

36 Williams, note 27 above, 76, 79, 122-5; Weisbrot, note 14 above 15-18. 
people, and under his leadership, peaceful protestors endured the savage assaults of racist mobs, tacitly supported by complicit authorities and officials, and the raw ugliness of American racial animus was revealed to a horrified and now largely sympathetic nation. ${ }^{37}$

\section{INTELLECTUAL PROPERTY EMPOWERMENT AS CIVIL AND HUMAN RIGHTS IN THE 21ST CENTURY}

Problems of social inequity or injustice can arise from any number of causes and are not always directly attributable to flaws or gaps in the law. Economic upheavals, outmoded social mores and even beneficial but unregulated technological advance can result in social developments inimical to the public good. ${ }^{38}$ However, when the law is in fact the direct cause of a pernicious social condition, the modality of redress is necessarily diandrous. Effective reform requires remedial change in the law, which must then be reinforced with positive social action, such as ameliorating public attitudes and awareness, restructuring institutional priorities and adopting detersive legislation and policies. ${ }^{39}$

The Civil Rights Movement is the modern exemplar of efficacious law-centered social action. When Charles Houston became the NAACP's Special Counsel in 1935, his legal theories gave the NAACP's civil rights agenda an articulable legal strategy. The relationship between Charles Houston's legal strategies and the NAACP's social action campaigns was therefore strategically symbiotic: public social action helped to raise awareness of the plight of African Americans under Jim Crow and to create a more receptive environment for civil rights litigation and legal

37 Williams, note 27 above 133, 138-9, 148-52; Bullard, note 35 above, 22-35.

38 Hannibal Travis, "Cyberspace As a Product of Public-Private Censorship", in Hannibal Travis (ed.), Cyberspace Law (Routledge, New York 2013), 1; Allen S. Hammond, "Symposium Bridging the Digital Divide in the Information Age: The Digital Divide in the New Millennium", 20 Cardozo Arts \& Ent. L.J. 135, 141-5 (2002); Nicholas W. Allard, "Digital Divide: Myth, Reality, Responsibility", 24 Hastings Comm. \& Ent. L.J. 449, 451-53, 458-65 (2002). ("In some parts of [Kentucky and the Ohio River Valley] a 'lap top' is where the kitty cat sleeps. A 'mouse' lives in the barn. 'Click' is what you do with your gun, and 'double click' is what you do when you are really serious.")

39 Richard L. Abel, "Law Without Politics: Legal Aid Under Advanced Capitalism”, 32 UCLA L. Rev. 474, 576-9, 600-2 (1985); see generally David M. Trubek, "Symposium: Back to the Future: The Short, Happy Life of the Law and Society Movement”, 18 Fla. St. U.L. Rev. 4 (1990). 
reform; the ensuing litigation victories brought credibility to the public campaigns and inspiration to the civil rights rank and file; this in turn led to an evolution of civil rights activist stratagems into a nationwide movement for positive legislative and social reform. ${ }^{40}$

The Civil Rights Movement is thus the issue and tactical forebear to Intellectual Property Empowerment. In the strategic tradition of the Civil Rights Movement, the Intellectual Property Empowerment agenda calls for progressive change in the application of intellectual property law to be combined with commensurate action in the socio-economic sector. Accordingly, the achievement of Intellectual Property Empowerment requires (i) an articulable legal theory and (ii) a compatible social action platform.

\section{The Legal Theory of Intellectual Property Empowerment: Intellectual Property Social Justice}

In formulating a litigation strategy to dismantle legalized segregation, Charles Houston devised a legal theory that not only targeted a practical weakness in the Jim Crow socio-legal infrastructure but was also rooted in the Constitution. Similarly, the legal theory of intellectual property social justice also finds its beginnings in a constitutional edict. In the United States, the Constitution expressly authorizes Congress to provide for intellectual property protection as a means by which to "promote the progress of the arts and sciences". ${ }^{41}$ The importance of this protection to the Framers of the Constitution cannot be overstated, given that it appears not in the Bill of Rights or subsequent Amendments, but in the very first Article of the Constitution. Moreover, the articulated social utility function of such protection is to stimulate intellectual property production, dissemination and re-ignition inuring to the greatest societal good. Thus, the constitutional scheme is dependent upon the broadest possible participation: the nation's cultural and technological advancement requires the creative and inventive contributions of all of her citizens.

Notwithstanding the constitutional directive, intellectual property exclusion, inequity and injustice have a long history in America. From the age of chattel slavery and throughout the era of Jim Crow and beyond, African Americans and other marginalized groups have been robbed of the credit for and economic fruits of many of their intellectual property achievements. Slaves, being property themselves, could not

40 Brown-Nagin, note 12 above, 722-6.

41 U.S. Constitution, Article I, Section 8. 
hold patents as a matter of law. ${ }^{42}$ From Bessie Smith to Elijah McCoy to Henrietta Lacks, the artistic revelations, technological inventions, scientific contributions and entrepreneurial innovations of African Americans have been systematically misappropriated or undermined by majority enterprises and individuals who enjoy the advantages of racial and financial capital. ${ }^{43}$

The recent case of Mixed Chicks, LLC provides an illustrative example. As bi-racial women, Mixed Chicks co-founders Wendy Levi and Kim Etheredge were well aware of the lack of hair care product options for bi-racial women of color. Beginning in 2003, Levi and Etheredge worked with a chemist to develop a line of hair care products, which they then sold to salons and beauty supply chains across the country. Eventually Sally Beauty Supply, LLC, the world's largest retailer of professional beauty supplies, approached Levi and Etheredge with an offer to distribute their products, which Levi and Etheredge declined. Thereafter, Sally Beauty introduced a line of hair care products for bi-racial women called "Mixed Silk", utilizing product textures, scents, packaging and marketing (including an Internet search engine that directed searches for "Mixed Chicks" to "Mixed Silk") that so closely resembled the Mixed Chicks product line that many Mixed Chicks customers were confused into thinking that "Mixed Silk" was simply a less expensive product line being offered by Mixed Chicks. ${ }^{44}$

Unlike many intellectual property start-up entrepreneurs, particularly those in marginalized communities, Levi and Etheredge had access to the resources needed to pursue intellectual property litigation against Sally Beauty. In a rare dispensation of intellectual property social justice, the

42 Patricia Carter Sluby, note 8 above, $10-15 ; 30-36$.

43 Van Smith, "Wonder Woman: The Life, Death, and Life After Death of Henrietta Lacks, Unwitting Heroine of Modern Medical Science", City Paper, 17 April 2002, accessed 10 October 2014 at http://www2.citypaper.com/news/story. asp?id=3426\&p=2; Kia Makarechi, "Robin Thicke Sues Marvin Gaye's Family To Protect 'Blurred Lines"', accessed 10 October 2014 at www.huffingtonpost. com/2013/08/16/Robin-Thicke-Sues-Marvin-Gaye's-Family-To-Protect-'Blurred Lines'_n_3767108.html; K.J. Greene, "Copyright, Culture \& Black Music: A Legacy of Unequal Protection”, 21 Hastings Comm. \& Ent. L.J. 339, 340-1 (1999); Keith Aoki, "Distributive and Syncretic Motives in Intellectual Property Law (With Special Reference to Coercion, Agency and Development)", 40 U.C. Davis L. Rev. 717, 722-4, 738-48, 755-68 (2007); Butler, note 16 above, 48-62.

44 Lisa Shuchman, "Mixed Chicks Gets $\$ 8.5 \mathrm{M}$ Jury Award for Infringing Mixed-Race Hair Products", accessed 10 October 2014 at http://intervalrecognized.blogspot.com/2012/12/the-multiracial-advocacy-blog-mixed.html; 35 Trials Digest 16th 13, 2012 WL 8963677 (C.D.Cal.). 
court permitted the case to reach the jury, which returned a verdict for Mixed Chicks. ${ }^{45}$

Unfortunately the Mixed Chicks outcome is atypical. More often than not, marginalized innovators and artists lack the information and financial resources to protect their rights and interests, and thus rather than incentivizing intellectual property endeavor in these communities, the intellectual property system in practice discourages it. Accordingly, the relationship between intellectual property social utility and intellectual property social justice is interdependent and symbiotic. To assure the greatest possible "progress of the arts and sciences", the intellectual property law must be formulated, interpreted and enforced such that all Americans enjoy equal incentives and opportunities to contribute to the national intellectual property storehouse. ${ }^{46}$

The social justice theory of intellectual property law acknowledges socially equitable inclusion, access and empowerment as fundamental objectives of intellectual property protection. Socially equitable access to books, inventions and other artistic and innovative works and accomplishments, irrespective of wealth, class, race, or gender status, ensures that the widest possible audience of minds and hearts will find the inspiration to conceive, express and invent. Socially just application and enforcement of intellectual property rights protects the interests of marginalized and developing world creators and inventors and preserves their incentives not only to produce but also to disseminate intellectual property output. Socially balanced exploitation of intellectual property product equalizes health and education standards, promotes civic and entrepreneurial endeavor and fosters universal respect for the intellectual property regime. ${ }^{47}$

45 This victory is reminiscent of Granville T. Woods' successful defense of his intellectual property rights against the machinations of Thomas Edison a century before. See Butler, note 16 above, 61-2; http://web.mit.edu/invent/iow/woods. html, accessed 10 October 2014.

46 Institution for Intellectual Property and Social Justice Enforcement Comments on IP Enforcement by the Federal Government, accessed 10 October 2014 at http://infojustice.org/wp-content/uploads/2012/08/IIPSJ.pdf; Rita Heimes, "Trademarks, Identity and Justice", 11 John Marshall Rev. of Intell. Prop. L. 133, 145-55 (2011).

47 Steven D. Jamar and Lateef Mtima, "A Social Justice Perspective on Intellectual Property, Innovation, and Entrepreneurship", in Megan M. Carpenter (ed.), Entrepreneurship and Innovation, Evolving Economies (Edward Elgar, Cheltenham, UK and Northampton, MA, USA 2012), 89-101; Cristian Timmermann, "Life Sciences, Intellectual Property Regimes and Global Justice", 18-34, accessed 10 October 2014 at http://www.academia. edu/4963224/_2013_Life_Sciences_Intellectual_Property_Regimes_and_Global_ Justice; Shubha Ghosh, Identity, Invention, and the Culture of Personalized 
IP social justice-conscious lawyers can deploy the Houston strategy by identifying and litigating appropriate intellectual property disputes to build a body of IP social justice precedents and jurisprudence. Indeed, some courts have begun to render social justice-minded decisions that protect the intellectual property rights of historically marginalized rights holders. Recently federal courts have ruled that video game purveyors that create avatars of college athletes without their permission violate the athletes' intellectual property rights. Cognizant of a system wherein colleges and universities, coaches and television networks earn billions off the talent and skill of student athletes, many of whom hail from inner city communities and rural towns and all of whom are prohibited by collegiate competition rules from profiting from their athletic exploits, courts are becoming increasingly intolerant of industry practices that deprive historical marginalized and other student athletes of their fair share of the intellectual property bounty. ${ }^{48}$

Courts have also begun to acknowledge the intellectual property law's social justice obligations beyond those of remedial justice and to otherwise inform their assessments of the law's social utility function. ${ }^{49}$ Recently a federal court held that an initiative by a group of universities to make digital scans of books in their libraries, so as to render them accessible to the blind and amenable to digital scholarly research, is a fair use, citing, among other things, "the unprecedented ability of print-disabled individuals to have an equal opportunity to compete with their sighted peers". ${ }^{50}$

Medicine Patenting, 179-84, 194 (Cambridge University Press, New York 2012); Sunder, note 10 above, 173-99.

48 Hart v. Elec. Arts, Inc., 717 F.3d 141(3d Cir. 2013); In re NCAA StudentAthlete Name \& Likeness Licensing Litigation, No. 10-15387, 2013 WL 3928293, (9th Cir. 31 July 2013); see Rev. Jesse Jackson, "Big Money for College Sports, Nothing for Players", accessed 10 October 2014 at http://www.suntimes.com/ news/jackson/26549238-452/big-money-for-college-sports-nothing-for-players. html\#.U5OgGE0U_IU.

49 The Authors Guild vs. Google, Inc., 770 F. Supp. 2d 666, 679 (S.D.N.Y. 2011), citing Lateef Mtima and Steven D. Jamar, "Fulfilling the Copyright Social Justice Promise: Digitizing Textual Information", 55 N.Y.L. Sch. L. Rev. 77, 79-80 (2010); Sean Flynn, "Human Rights and Access to Medicines Cases" (27 April 2013), accessed 10 October 2014 at infojustice.org/archives/29409.

50 The Authors Guild, Inc. v. HathiTrust, 902 F. Supp. 2d 445 (S.D.N.Y. 2012), affirmed, 2014 U.S. App. LEXIS 10803; see also William Patry, How to Fix Copyright, 10 (Oxford University Press 2011) "[T]he inability of the blind and other visually impaired people to have access to printed...copies of books should be the copyright civil rights issue of our time. In the wealthiest countries, only some 5 percent of published books are made accessible in formats the visually impaired can use; this figure drops to less than 1 percent in poorer countries. Copyright laws are the principal reason for this scandal." 
Similarly, another federal court has held that the Google Books Project, which undertook digital scans of books in several university libraries in order to enhance public access to, scholarly research in, and archival preservation of these books, is also a fair use..$^{51}$

Consideration for intellectual property social justice has also begun to impact judicial determinations in the developing world. Recently, India's Intellectual Property Appellate Board affirmed a decision by the India Patent Office to allow a local manufacturer to produce a generic version of the patented cancer drug Nexavar, in order to make the drug available to the public at an affordable price. ${ }^{52}$ Similarly, the India Supreme Court rejected a challenge to the production of inexpensive generic versions of the cancer drug Glivec, and further held that an application to patent a "newer version" of the drug was essentially an attempt to extend the term of the expiring Glivec patent. ${ }^{53}$ These decisions reflect an evolving judicial sensitivity to the relationship between prevailing intellectual property precepts and the failure to address various health crises and other socioeconomic problems which persist in the developing world. ${ }^{54}$

51 The Authors Guild, Inc. v. Google, Inc., 05 CV813 6 (DC) (S.D.N.Y. 2013). These decisions herald a continuing evolution of judicial application of fair use, from the groundbreaking theories of "aesthetic transformation" formulated by Judge Pierre Leval, to Internet indexing as "functional transformation", to what might arguably be characterized as "social justice transformation", which would include uses essential to promoting cultural preservation, diversity, and parity in the digital information age. See Lateef Mtima, "The Promise of Information Justice", in Travis (ed.) Cyberspace Law, note 38 above, 69. For an excellent analysis of the contemporary judicial approach to fair use, see Patricia Aufderheide and Peter Jaszi, Reclaiming Fair Use (University of Chicago Press, Chicago 2011), 80-93.

52 Cancer Drug Ruling Seen As Victory for the Poor, accessed 10 October 2014 at http://www.stuff.co.nz/business/world/8386127/Cancer-drug-ruling-seenas-victory-for-poor; India Board Rules Against Bayer in Cancer Drug Patent Case, accessed 10 October 2014 at http://www.reuters.com/article/2013/03/04/us-indiabayer-idUSBRE9230LC20130304.

53 Amy Kapczynski, "Engineered in India - Patent 2.0", The New England Journal of Medicine, 8 August 2013, accessed 10 October 2014 at http://www.nejm. org/doi/full/10.1056/NEJMp1304400; Human Rights Win as Big Pharma 'Novartis' Loses Patent Case, accessed 10 October 2014 at https://www.commondreams.org/ headline/2013/04/01-3.

54 One of the most important examples of IP social justice progress is the recent adoption of the Marrakesh Treaty to Facilitate Access to Published Works by Visually Impaired Persons and Persons with Print Disabilities on 28 June 2013, signed by 51 countries. See The 2013 Marrakesh Treaty: Providing Access to Copyrighted Works for the Blind and Print Disabled, accessed 10 October 2014 at http://www.pijip.org/events/marrakesh/; From Book Famine to Book Banquet: 
Intellectual property social justice theory further conceptualizes equitable participation in intellectual property production and consumption as a civil and human right. ${ }^{55}$ By employing Houston's strategy, intellectual property attorneys can promote and enhance judicial recognition of the law's social justice obligations. ${ }^{56}$ Promulgated in concert with a progressive social action platform, intellectual property social justice implements positive Intellectual Property Empowerment.

\section{The Intellectual Property Empowerment Social Action Platform: Embracing Entrepreneurship}

When people are suffering ... they don't want rhetoric and processes which seem to go slowly ... they want direct participation. They want to be able to say, 'What I'm doing here gives me power and is going to help us change this business. ${ }^{57}$

While a social justice-centered interpretation of the intellectual property law will redress certain injustices and social problems which plague historically marginalized and developing communities, the impact on their economic advancement will be limited unless they also produce and protect intellectual property which they can exploit. Just as the carefully constructed campaign of mobilizing strategies, including public marches, sit-ins and other acts of civil protest provided inspiration, direction and opportunity for ordinary individuals to move the frontline of the Civil Rights Movement from the courts to the streets, a campaign of Intellectual

Ghana Gets Ready for Ratification, accessed 10 October 2014 at http://www. eifl.net/news/book-famine-book-banquet-ghana-gets-ready. Intellectual property social justice thus transcends notions of redistributive justice or particular theoretical bases (that is, positive law or natural rights) for IP protection. See further Chapters 8, 11, and 12 .

55 See e.g. Steven D. Jamar, "Symposium: The Global Impact and Implementation of Human Rights Norm: A Social Justice Perspective on the Role of Copyright in Realizing International Human Rights", 25 Pac. McGeorge Global Bus. \& Dev. L.J. 289, 290-7 (2012); Laurence R. Helfer, "Toward a Human Rights Framework for Intellectual Property”, 40 U.C. Davis L. Rev. 971, 976-82, 1015-20 (2007); Margaret Chon, "Intellectual Property and the Development Divide", 27 Cardozo L. Rev. 2821, 2823-9, 2876-8, 2885-97, 2909-12 (2006); Julie E. Cohen, "Creativity and Culture in Copyright Theory", 40 U.C. Davis L. Rev. 1151, 1197-8 (2007). See Chapters 6, 8, and 12.

56 Lateef Mtima, "The Promise of Information Justice", in Travis (ed.) Cyberspace Law, note 38 above, 57-8, 70.

57 James Lawson, social activist and Dr. King's advisor on non-violent protest, quoted in Williams, note 27 above, 123 (emphasis added); Weisbrot, note 14 above, 21 . 
Property Empowerment similarly requires appropriate mobilizing strategies to promote communal intellectual property awareness, education and grassroots engagement "to help us change this business".

The proposition that development and exploitation of intellectual property will promote socio-economic empowerment can seem somewhat abstract to the average person. To capture attention, spark imagination and motivate action, Intellectual Property Empowerment objectives must be concretely aligned with the socio-economic perspectives and priorities of the target community. The Civil Rights protest movement gave voice to decades of frustration with Jim Crow oppression and provided people with the means to directly challenge that system. Intellectual property-oriented social action should be similarly directed toward the frustrations with (i) the perennial lack of individual economic opportunities and (ii) the historic and ongoing misappropriation of marginalized community and developing nation TKE and IP output, and presented as an avenue toward personal economic autonomy and communal socio-economic empowerment.

Principles and strategies of entrepreneurship provide an accessible and pragmatic structure for intellectual property-oriented social action in underserved communities and developing nations. In the tradition of teaching the hungry to fish, the entrepreneur offers a romantic and enticing image of self-empowerment in hostile terrain. ${ }^{58}$ This is one reason why there is a long tradition of immigrant socio-economic upward mobility through "middleman" entrepreneurship and other engagement in "undesirable" but essential enterprise, as evident in the experiences of some European Jews, East African Asians, Japanese Americans and South African Indians, among others. ${ }^{59}$ Even African Americans, who were denied most of the opportunities for "middleman" entrepreneurial socio-economic mobility enjoyed by America's voluntary immigrants, have a long tradition of entrepreneurial enterprise. ${ }^{60}$ Thus entrepreneurship is a familiar and proven empowerment path for many marginalized individuals and communities.

58 David E. Pozen, "We Are All Entrepreneurs Now", 43 Wake Forest L. Rev. 283, 285-7 (2012); Eric J. Gouvin, "Of Small Businesses and Entrepreneurs: Toward a Public Policy that Supports New Venture Formation, Entrepreneurship and Innovation", in Megan M. Carpenter (ed.), Entrepreneurship and Innovation in Evolving Economies (Edward Elgar, Cheltenham, UK and Northampton, MA, USA 2012), 27-9, 37-8.

59 Butler, note 16 above, $1-33$.

60 Rogers, note 13 above, xviii-xx, 27-38, 59-63, 84; Butler, note 16 above 68-78, 143-64, 224-5; Patricia Carter Sluby, The Entrepreneurial Spirit of African American Inventors (Praeger, Westport 2011), 23-66. 
Moreover, entrepreneurial solutions are particularly well-suited to addressing some of the special socio-economic problems with which many historically marginalized communities and developing nations currently grapple. Affordable access to knowledge and pharmaceutical drugs, empowering vocational training and conquering endemic diseases such as sickle cell anemia all require innovative but affordable, cost-effective solutions. ${ }^{61}$ Thus, entrepreneurially-focused intellectual property activity can be responsive to many imminent marginalized community and developing nation socio-economic needs.

By definition, entrepreneurial intellectual property endeavor involves the development and commercial exploitation of new intellectual property or at least the innovative commercial application of pre-existing intellectual property. ${ }^{62}$ Intellectual Property Empowerment, however, does not promote intellectual property commercial enterprise for its own sake: the primary goal is communal socio-economic progress and empowerment. Consequently it is important to identify entrepreneurial theories or mechanisms that are most consistent with this overarching social objective and to contextualize them in the larger civil and human rights discourse.

\section{Intellectual Property Empowerment and Social Entrepreneurship: A Civil Rights Historical Perspective}

We have seen how Civil Rights legal theory can inform Intellectual Property Empowerment legal theory. Similarly, the history and structure of the Civil Rights social action strategy can help to shape the Intellectual Property Empowerment social action platform. Certain aspects of the African American socio-economic struggle are particularly resonant with the intellectual property socio-economic empowerment agenda. Intellectual property injustice conflates cultural misappropriation and economic subjugation, ${ }^{63}$ presenting a socio-economic landscape similar to that which made economic progress an aspect of the political agendas of

61 See Carpenter (ed.), Entrepreneurship and Innovation in Evolving Economies, note 58 above; Banji Oyelaran-Oyeyinka and Padmashree Gehl Sampath, Latecomer Development: Innovation and Knowledge for Economic Growth (Routledge, New York 2010).

62 William D. Bygrave, "The Entrepreneurial Process", 49-56, in William Bygrave and Andrew Zacharakis (eds), Entrepreneurship (2nd edn, John Wiley \& Sons, Chichester, 2011); Oyelaran-Oyeyinka and Sampath, note 61 above 7-10; Michael Golin, Driving Innovation: Intellectual Property Strategies For a Dynamic World (Cambridge University Press, New York 2008), 11-21.

63 Otha Richard Sullivan, African American Inventors (John Wiley \& Sons, Hoboken 1998); Greene, note 8 above, 1183-9, 1196-9. 
all of the major black leaders. ${ }^{64}$ Economic advancement held the utmost priority for Booker T. Washington, and for Marcus Garvey its importance was second only to black racial pride. ${ }^{65}$ And while legal and social equality took precedence for W.E.B. Du Bois, economic justice was certainly an important component of his political agenda. ${ }^{66}$

A key element of Du Bois' vision for African American uplift was his concept of a civically capable and socially sanguine "Talented Tenth" leadership caste, ${ }^{67}$ who Du Bois reasoned would helm African American progress, including the community's economic advancement. In terms of entrepreneurial classification, Du Bois' "Talented Tenth Economic Uplift" is perhaps best considered as a model of "classic" entrepreneurship. Classic "creator/destroyer" entrepreneurship is generally defined in terms of individual innovation and risk taking in business enterprise that introduces new products, services or practices and ultimately revolutionizes the market place by displacing predecessors in the market. ${ }^{68}$ In a similar fashion, Talented Tenth Economic Uplift anticipates a measure of unprecedented economic endeavor in the majority marketplace by a select group of African Americans, displacing segregated enterprise and eventually contributing to the socio-economic transformation of the African American community and the American marketplace as a whole.

Evaluating African American economic progress during and since the

64 Brown-Nagin, note 12 above, 728-30; Gavin Wright, Sharing the Prize: The Economics of the Civil Rights Revolution in the American South (Harvard University Press, Cambridge, MA 2013), 10-15. African American economic empowerment ideology therefore transcends mere economic progress, and like Intellectual Property Empowerment, its scope encompasses political autonomy and cultural dignity.

65 Washington, note 28 above 106-7; Garvey, note 30 above, 48, 56.

66 See e.g. W.E.B. Du Bois, 14(4) The Crisis, 163-6 (1917); Wright, note 64 above, 224-5; Grant, note 17 above, 206-9. In addition to backing Charles Houston's litigation strategies to desegregate public education, the NAACP also supported Houston's litigation against railroad labor unions, which forced blacks out of the industry to placate their southern white membership. Houston would successfully argue before the United States Supreme Court that by virtue of their exclusive collective bargaining rights, the unions owed a fiduciary obligation to represent the interests of all their trade members, including blacks. See James, note 21 above, 166-73; McNeil, note 17 above, 156-8, 168-71.

67 Harry T. Edwards, "The Journey from Brown v. Board of Education to Grutter v. Bollinger", 102 Mich. L. Rev. 944, 949-50 (2004); Kevin Brown and Jeannine Bell, "Symposium: The School Desegregation Cases and the Uncertain Future of Racial Equality: Demise of the Talented Tenth: Affirmative Action and the Increasing Underrepresentation of Ascendant Blacks at Selective Higher Educational Institutions”, 69 Ohio St. L.J. 1229, 1239-42 (2008).

68 Pozen, note 58 above, 287-93; Gouvin, note 58 above, $30-1$. 
Civil Rights era, it seems fair to say that Talented Tenth Economic Uplift has not resulted in pervasive economic progress for the African American community. There are various factors to which this might be attributed. First, many pre-integration black business ventures were undertaken principally to address unmet African American needs in rigidly segregated markets, and thus were only "low" or "quasi-entrepreneurial" in nature. Although "lone wolf" risk takers would identify and service unmet needs, they could typically do so without employing innovative products, services or mercantile practices; the restrictions of segregation necessitated only the provision of "black alternatives", such as black barbers and undertakers. Once these markets proved profitable, however, majority business entities, particularly in the post-segregation era, could easily displace or absorb black operators. Thus, while some pioneering individuals initially did well, often there was little permanent, community-wide economic advancement. ${ }^{69}$

When black entrepreneurs did innovate, their "uneasy relationship" with the intellectual property regime often permitted non-blacks to misappropriate their innovations. Unlike Granville T. Woods or Mixed Chicks, most black entrepreneurs lacked the resources to procure and protect their intellectual property rights, thus non-black competitors could offer "knock-offs" of black innovations and otherwise usurp the markets that blacks actually created. Consequently, even when blacks engaged in classic "creator/destroyer" entrepreneurial activity, neither the individual entrepreneur nor the African American community was able to capture or retain the full economic benefits. ${ }^{70}$ Moreover, "creator/destroyer" displacement of segregated black enterprise did not always lead to substitute opportunities in the majority marketplace, which resulted in a net loss to the post-integration community.

Finally, it should be understood that the first order of Talented Tenth Economic Uplift is not economic advancement in the ordinary sense, but rather, support for Du Boisian socio-legal equality. Accordingly, social advancement goals such as underwriting college and professional educations for family members was often prioritized over business reinvestment or expansion, and without subsequent application of the acquired professional skills to the family enterprise. The history of the Imperial Broom Company, a five-generation African American business which

69 Benjamin Means, "A Lens for Law and Entrepreneurship", 6 Ohio St. Entrepreneurial Bus. L. J. 1, 9, 13 (2010-11); Gavin Wright, 223-5, 227.

70 Butler, note 16 above, 203-4, 217-23; Rogers, note 13 above, 84-90, 95-98; Wright, note 64 above, 223-8. 
began operation in 1900, is a typical example. A rare African American "middleman" enterprise which successfully serviced mainstream markets, the business would ultimately underwrite professional degrees for three generations of family descendants. However, after more than a century of continuous and profitable operation, the company has all but closed its doors, in part due to a lack of family members whose professional careers are compatible with undertaking management of the company. ${ }^{71}$

From one perspective, Imperial Broom represents a successful application of Talented Tenth Economic Uplift. ${ }^{72}$ For Du Bois, African American social equality was paramount and the expansion of the black professional class and its diffusion into mainstream society was a central objective of his agenda. In the post-Civil Rights/information society, however, "pure" economic progress has moved to a higher position on the list of priorities, not only for African Americans but for many marginalized communities and developing nations. Consequently the pursuit of Intellectual Property Empowerment and similar objectives warrant alternative entrepreneurial strategies and goals.

In contrast to W.E.B. Du Bois, Booker T. Washington not only placed the highest priority on black economic advancement, but he also advocated for entrepreneurship and business development as an egalitarian path that all blacks could pursue. Even under "anything-but-equal" Jim Crow, every African American could "cast down her bucket" and gather up the meager opportunities available to her. Washington argued that while whites might shun blacks socially, they would do business with blacks in circumscribed fields, and as blacks excelled in permissible areas of endeavor, the social barriers between the races would eventually give way. ${ }^{73}$

From an entrepreneurial perspective, Washington's “Equality through Economics" philosophy might best be understood as a form of "social" entrepreneurship. Social entrepreneurship is distinguished from classic entrepreneurship by virtue of the social entrepreneur's driving motivation: the achievement of some objective of social change or progress through

71 Elizabeth Cogar, 'Sweeping Questions', Style Weekly, 5 January 2005, accessed 10 October 2014 at http://www.styleweekly.com/richmond/sweepingquestions/Content?oid=1379833; Notable Henricoans Database, accessed 10 October 2014 at http://events.henricolibrary.org/nhdb/.

72 Wright, note 64 above, 234-5.

73 Washington, note 28 above, 106-7, 114-15; Rogers, note 13 above, 81-4. Although Marcus Garvey shared Washington's emphasis on economic empowerment, his overarching strategy advocated repatriation to Africa, and thus was ultimately parallel to the Civil Rights Movement. 
entrepreneurial endeavor. ${ }^{74}$ While the social entrepreneur certainly seeks monetary profit in her business pursuits, such returns are not the end-goal of the enterprise but are considered the means by which to achieve her social agenda.

Washington's Equality through Economics ("ETE") philosophy can be considered as social entrepreneurship for several reasons. First, the principal goal is not monetary profit but social change through business endeavor: through successful business enterprise, blacks could attain a respected place in society. Indeed, the amount of profit is not particularly important. Even if she only makes enough to live on, the black entrepreneur or business person gains a measure of autonomy while at the same time demonstrating her valuable function in society. Moreover, Washington's ETE ideology tends to subordinate individual aspirations and preferences in favor of communal social progress. Indeed, much of the Talented Tenth distaste for Washington's philosophy stemmed from his willingness to accept the relegation of blacks to menial crafts and trades, irrespective of the more sophisticated vocational appetites and aptitudes of many educated blacks. In many ways, Equality through Economics bespeaks more of a plan for the social elevation of African Americans, than of a capitalist agenda for individual wealth enhancement. ${ }^{75}$

In light of the legal and social gains achieved through the Civil Rights Movement, an application of ETE social entrepreneurship presents a viable social action platform for African American and other Intellectual Property Empowerment initiatives. First, the need to prioritize economic development should be self-evident. While the struggle for black legal and social equality has not been won completely and should not be abandoned, changed circumstances and opportunities warrant a new emphasis on economic justice. By employing intellectual property protection to promote communal economic advancement, the African American community takes full socio-economic advantage of its most valuable resource: its creative and inventive capability.

Second, the ETE social entrepreneurship approach is consistent with cooperative enterprise, which is essential to Intellectual Property

74 John Whitman, "Social Entrepreneurship: An Overview”, 563-6, in Bygrave and Zacharakis (eds), Entrepreneurship; Roger Spear, Social Entrepreneurship: $A$ Comparative Perspective, Businesses With A Difference, 202-4 (University of Toronto Press, Toronto 2012); Pozen, note 58 above, 294-8.

75 Washington, note 28 above, 114-15; Butler, note 16 above, 151-2; Wright, note 64 above, 225-6, 234; Danielle M. Conway, "Promoting Indigenous Innovation, Enterprise, and Entrepreneurship Through the Licensing of Article 31 Indigenous Assets and Resources”, 64 SMU L. Rev. 1095, 1096-8, 1101-3 (2011). 
Empowerment. ${ }^{76}$ Intellectual property development, protection and commercial exploitation can sometimes be prohibitively expensive. Whereas copyright registration can be had for a nominal $\$ 35$ fee, pursuing even a relatively simple patent application can cost tens of thousands of dollars. ${ }^{77}$ Many African American inventors, artists and entrepreneurs simply lack the resources to pursue "lone-wolf" intellectual property entrepreneurship. Those who insist on "going it alone" often end up watching their ideas die on the vine, or desperate to avoid such an outcome, they sell out their interest for a fraction of its worth after having rejected more equitable, communal cooperative opportunities. Ironically, many of those who more readily agree to cooperative ventures actually have the resources to pursue their projects independently, but they recognize that equitable communal cooperation not only spreads the risk, it can also economically empower the community as a whole.

Finally, ETE social entrepreneurship would promote enterprise that targets pressing intellectual property-related needs in the African American community. ${ }^{78}$ Whether or not addressing the community's access to knowledge and affordable medicines deficiencies presents the most lucrative business opportunities, the mandate of Intellectual Property Empowerment is not indiscriminate wealth maximization, but rather, communal socio-economic progress. ${ }^{79}$ Indeed, where the African American intellectual property owner's pecuniary objectives conflict with this goal, social entrepreneurship resolves the conflict in favor of her community.

76 Henderson, note 2 above, 140-2; Roger Spear, note 74 above, 210-11; Pozen, note 58 above, 331 .

77 http://www.copyright.gov/docs/fees.html; http://www.uspto.gov/web/offices/ ac/qs/ope/fee010114.htm, accessed 10 October 2014.

78 See Victoria F. Phillips, "Symposium, Commodification, Intellectual Property and the Quilters of Gee's Bend", 15 Am. U. J. Gender Soc. Pol'y \& L. 359, 363-70 (2007) (discussing a highly successful communal social entrepreneurship business through which local women sell indigenous culture quilts). I have asked entrepreneurship and entertainment law experts to explore ideas for similar enterprises, including low-cost online community IP education programs staffed by pro bono attorneys, IP litigation support for marginalized clients provided on a quasi-contingency/royalty assignment basis, and tax shelter/trust and estate advice provided in conjunction with IP social justice trust and foundation formation. Some applications of these proposals are discussed in Chapter 10.

79 Whitman, note 74 above, 566-70. 


\section{Applying ETE Social Entrepreneurship to Other IP Empowerment Contexts}

Although there is no "one size fits all" approach to Intellectual Property Empowerment, ETE social entrepreneurship can be adapted to a variety of Intellectual Property Empowerment contexts. For example the Grameen Bank, which provides "solidarity loans" to groups of impoverished villagers in India, might be considered an exercise in ETE social entrepreneurship. Grameen lending effectively addresses imminent socio-economic deficiencies by investing in underutilized human capital, by extending loans which are "collateralized" by communal collaboration: the members of each borrower group undertake collective responsibility to ensure that each member repays her individual loan. ${ }^{80}$ By assessing the pertinent socio-political history, cultural traditions and economic conditions and priorities of the subject community, ETE social entrepreneurship can be similarly applied to a wide variety of intellectual property-related socioeconomic problems.

\section{IMPLEMENTING INTELLECTUAL PROPERTY EMPOWERMENT: ENGAGING COLLABORATIVE ACTION}

Intellectual Property Empowerment is intended as a socio-economic movement comprised of (i) intellectual property social justice legal theory, which is based on the principle that the social utility objectives underlying IP protection can only be achieved through legal norms that assure socially equitable IP participation for all; and (ii) a social action plan centered around social entrepreneurship, and which requires incentivized "IP social activists", equipped with a command of basic intellectual property principles.

Intellectual Property Empowerment is an adaptable social action tool. It can be implemented as a linear, grassroots organizational strategy in principal stages of (i) intellectual property social justice theory dissemination/community IP education; (ii) identification of and devising solutions for communal/development IP social priorities, deficiencies and long-term goals; and (iii) redressing systemic IP social deficiency through law and policy initiatives. Alternatively, Intellectual Property Empowerment can be implemented through modular and targeted application, the topic/chapter

80 http://en.wikipedia.org/wiki/Grameen Bank, accessed 10 October 2014. 
arrangement of this book being one such example. Consistent with the collaborative nature of Intellectual Property Empowerment, IP social activist scholars, theorists and experts from a variety of fields herein consider the theory of intellectual property social justice and assess aspects or problems of IP Empowerment. Through Entrepreneurship and Empowerment, IP social activists apply the tools of social entrepreneurship to specific as well as systemic IP social deficiencies; through Education and Advocacy, IP social activists illustrate how communities and nations can be assisted with and empowered to undertake IP social reform; and through Engagement and Activism, IP social activists explore how IP social justice theory can be used to harmonize IP protection with broader social needs and development goals.

Collectively the contributors to this work provide a framework for the reorientation of prevailing intellectual property perspectives toward a more inclusive and cohesive global IP system. Our purpose is to inspire as much as it is to inform; if this volume sparks ideas and ignites action, the foundation for Intellectual Property Empowerment will have been laid. 
Lateef Mtima - 9781783470259 Downloaded from PubFactory at 04/26/2023 $03: 25: 36 \mathrm{PM}$ via free access 